\title{
Ortaokul Matematik Ders Kitaplarında Geometri ve Ölçme Konularına Yönelik Yapılan İspatların Muhakeme ve İspat Analitik Çerçevesi Kapsamında İncelenmesi
}

\author{
An Examination of Proofs on Geometry and Measurement in Middle School Mathematics Textbooks \\ within the Scope of Reasoning and Evidence Analytical Framework
}

Fatih KARAKUŞ ${ }^{1}$, Ebru KORKUTAN ${ }^{2}$

\begin{abstract}
Öz
Matematik öğretim programlarında son yıllarda yapılan güncellemeler ispat kavramının matematik eğitimindeki rolü ve önemini daha da arttırmıştır. Yenilenen matematik öğretim programlarında ispat etkinliklerine daha fazla yer verilmesinin hedeflendiği belirtilmektedir. Ders kitapları ise öğretim programlarında yapılan bu değişime ayak uydurmaya ve programlardaki reform çalışmalarını yansıtmaya çalışmaktadır. Bu bağlamda güncellenen öğretim programları doğrultusunda hazırlanan ders kitaplarında ispat etkinliklerine ne sıklıkla ve nasıl yer verildiğini incelemenin önemli olduğu söylenebilir. Bu çalışmanın amacı, 2013 ve 2018 yıllarında yapılan öğretim programlarındaki değişiklikler doğrultusunda yayımlanmış olan ortaokul 7. ve 8. sınıf matematik ders kitaplarında geometri ve ölçme alanında yer alan ispat etkinliklerinin kullanım sıklığını incelemektir. Bu amaçla Sivas ili bölgesinde 7. ve 8. sınıf matematik derslerinde kullanılan kitaplarda yer alan ve geometri ve ölçme öğrenme alanına yönelik ispat etkinlikleri incelenmiştir. Seçilen kitaplar Stylianides'in muhakeme ve ispat analitik çerçevesi kapsamında incelenmiştir. Elde edilen bulgular ders kitaplarında yer alan aktivitelerin çok az bölümünün ispat niteliği taşıdığını göstermektedir. Bunun yanında 2018 yılında ders kitaplarında yer alan ispat etkinliklerinin sayısının ise 2013 yılına göre azaldı̆̆ı belirlenmiştir.
\end{abstract}

Anahtar Kelimeler

İspat

Geometri ve ölçme öğretimi

Matematik ders kitab1

Ortaokul matematik öğretim programı

\section{Abstract}

Recent updates in mathematics education programs have increased the role and importance of the concept of proof in mathematics education. It is stated that it is aimed to include more proof activities in the renewed mathematics education programs. Textbooks, on the other hand, try to keep up with this change in the curriculum and reflect the reform efforts in the curriculum. In this context, it can be said that it is important to examine how often and how proof activities are included in the textbooks prepared in line with the updated curriculum. The aim of this study is to examine what extent proof tasks take place in the content standards of geometry and measurement in middle school 7th and 8th grade mathematics textbooks published in line with the changes in the curriculum in 2013 and 2018 . For this purpose, the proof tasks in the books used in 7th and 8th grade mathematics lessons in Sivas province region and related to geometry and measurement content standards were examined. The selected books were coded within Stylianides' reasoning and proof analytical framework. According to the findings, there were a few proof tasks in these books. In addition, it was determined that the number of proof tasks used in 2018 decreased compared to 2013.

Keywords

Proof

Teaching geometry and measurement

Mathematical textbook

Elementary school mathematics curriculum

$\begin{array}{lll}\text { Başvuru Tarihi/Received } & \text { Kabul Tarihi /Accepted } \\ 13.12 .2020 & 30.03 .2021 & \text { I Araştırma Makalesi / Research Article I }\end{array}$

\section{Suggested APA Citation/Önerilen APA Atıf Biçimi:}

Karakuş, F., \& Korkutan, E. (2021). An examination of proofs on geometry and measurement in middle school mathematics textbooks within the scope of reasoning and evidence analytical framework. Manisa Celal Bayar University Journal of the Faculty of Education, 9(1), 1-16. https://doi.org/10.52826/mcbuefd.840090

\footnotetext{
1 Sorumlu Yazar, Doç. Dr., Sivas Cumhuriyet Üniversitesi, Eğitim Bilimleri Fakültesi, Matematik ve Fen Bilimleri Eğitimi Bölümü, Sivas, TÜRKIYE; (i) https://orcid.org/0000-0001-9581-520X

2 Matematik Öğretmeni, Millî Eğitim Bakanlığı, Sivas, TÜRKİYE; (D) https://orcid.org/0000-0002-9705-3533
} 


\section{GİRIŞ}

Matematik yapısı itibariyle daha önceki öğrenmelerle sıkı sıkıya bağlı, birikimli bir bilimdir (Dikici, Güler ve Özdemir, 2012). Yeni bir bilginin öğrenilmesi sırasında önceki bilgilerle bir ilişki kurulmakta ve elde edilen yeni bilgi bir sonraki öğrenmeler için bir zemin görevi görmektedir. Bu nedenle yanlış veya eksik bir şekilde öğrenilen bilgi bir sonraki öğrenmeleri de olumsuz etkileyeceğinden sunulan bilgiler arasından doğru bilgilerin doğru şekillerde alınması çok önemli hale gelmektedir. Bu anlamda doğru bilginin ölçütü üzerine düşünmek kaçınılmaz bir gereklilik olarak karşımıza çıkmaktadır (Kaplan, Doruk, Öztürk ve Duran, 2016). Matematiksel bir bilginin doğruluğu üzerine düşünebilmek için neden ve nasıl gibi soru ifadelerini ön planda tutan bir düşünme yapısına ihtiyaç duyulduğunu söylemek mümkündür. Bu düşünme yapısı ile birlikte daha anlamlı, kalıcı ve içselleştirilmiş öğrenmelerin meydana geleceği kabul edilebilir bir gerçektir ve matematiksel öğrenmeler sırasında öğrencilerin muhakeme becerileri gelişmektedir. Öğrencilerin muhakeme becerilerini geliştirmekte ise matematiksel ispatlar önemli bir yere sahiptir (Dikici vd., 2012). Matematiksel bilgilerin kişiden kişiye değişmemesinin en önemli sebebi ispatlanabilir olmasıdır. Matematiksel ispatlar sayesinde diğer bilimlere göre matematik bilimi içerisinde doğru bilgiye ulaşmak daha kolay hale gelmektedir. Türk Dil Kurumu [TDK] (2005) ispatı, "Tanıt ve kanıt göstererek bir şeyin gerçek yönünü ortaya çıkarma, kanıtlama, tanıtlama, tanıt", ispat etmeyi ise "1) kanıtlamak, ... 2) tanıtlamak" (s.984-985) şeklinde ifade etmiştir. İspat kavramı kullanım yerine ve amacına göre farklı anlamlar ifade edebilmektedir. Hanna (2000) matematiksel ispatın amacını sadece bir önermenin doğru ya da yanlış olduğunu göstermek değil aynı zamanda neden doğru ya da neden yanlış olduğunun da açıklanması olarak ifade etmiştir. Ülkemizde ise Millî Eğitim Bakanlığı [MEB] tarafından 2013 yılında yapılan öğretim programı değişikliği ile birlikte mantıksal genellemeler ve çıkarımlarda bulunan, çıkarımların doğruluğunu ve geçerliğini savunabilen yani muhakeme becerisi kuvvetli bireylerin yetiştirilmesi gerektiği bir hedef haline gelmiştir (MEB, 2013).

Öğretim seviyelerine göre ispat kavramı düşünüldüğünde okulöncesi dönemden üniversite eğitimine kadar ispatın her sınıf seviyesinde farklı düzeylerde yer aldığı görülmektedir. İspat üzerine ulusal düzeyde yapılan çalışmaların (Altıntaş ve İlgün, 2020; Cihan ve Akkoç, 2020; Sevgi ve Kartalcı, 2021; Yeşilyurt-Çetin ve Dikici, 2020) birçoğunun öğrenciler, öğretmen adayları ve öğretmenlerin ispat becerileri ve ispat ile ilgili görüşleri üzerine olduğu görülmektedir. Öğrencilere bilişsel ve duyuşsal anlamda fayda sağladıkları için öğretimin her seviyesinde ispatlardan yararlanılması ya da ispatla ilgili becerilerin öğrencilere kazandırılması oldukça önemlidir (Kaplan vd., 2016). Bu nedenle ispata yönelik uygulamaların sınıf ortamına nasıl aktarılacağı önemlidir ve bunun için en önemli kaynak ders kitaplarıdır (Doğan, 2019). Bu yönüyle ele alındığında ispat kavramı yönünden ders kitaplarını incelemek önem arz etmektedir. Ders kitaplarını ispat kavramı yönünden inceleme çalışmalarına bakıldığında ise gerek yurt dışında gerekse ülkemizde ispat etkinliklerinin incelendiği çalışmalara rastlanmaktadır. Yurt dışında yapılan çalışmalarda (Bieda, Ji, Drwencke ve Picard, 2014; Fujita ve Jones, 2014; Hanna ve de Bruyn, 1999; Newton ve Newton, 2007; Stacey ve Vincent, 2009; Stylianides, 2009; Thompson, Senk ve Johnson, 2012;) ders kitaplarındaki ispat etkinlikleri konu ve sınıf seviyeleri bakımından incelenmiştir. Örneğin Stacey ve Vincent (2009) birbirinden farklı dokuz adet 8.sınıf ders kitabındaki etkinlikleri incelediği çalışmasında, etkinliklerin öğrencilerin çıkarım yapmalarını, yeni fikirler üretmelerini ya da kavramlar arasında ilişkiler oluşturabilmelerini desteklemediğini, buna karşın bu etkinliklerin daha çok kuralı bulmaya yönelik olduğunu belirtmiştir. Bunun yanı sıra Newton ve Newton (2007) İngiltere'de ilköğretim ders kitaplarını ispat etkinlikleri açısından incelemiştir ve kitaplarda ispat etkinliklerinin yeterli düzeyde yer almadığını ancak öğretmenler için ders kitaplarının bir rehber rolü üstlendiğinden dolayı ders kitaplarına daha fazla dikkat edilmesi gerektiğini vurgulamıştır. Ülkemizde de matematik ders kitaplarındaki matematiksel ispat etkinliklerini inceleyen çalışmalara (Doğan, 2019; Doğan, 2018; Gökkurt, Deniz, Akgün ve Soylu, 2014; Zeybek, Üstün ve Birol, 2018) rastlanmaktadır. Doğan (2019), 8. sinıf ders kitaplarını akıl yürütme ve ispat etkinliklerine ne oranda yer verildiği açısından incelerken Zeybek ve arkadaşları (2018) ise 5, 6, 7 ve 8. sınıf ders kitaplarında ispat etkinliklerine ne oranda yer verildiğini incelemiştir. Doğan (2019) matematik eğitimi içerisinde ispat etkinliklerinin önemini vurgularken ders kitaplarında yeterli düzeyde ispat etkinliklerinin yer almadığını ve bu durumun nedeninin açık olmadığını ifade etmiştir. Zeybek ve arkadaşları (2018) ise güncel

|Manisa Celal Bayar University Journal of The Faculty of Education, 2021, Vol. 9, No. 1 | 
eğitim reformları doğrultusunda hazırlanan öğretim programlarının hedefleri ile ders kitaplarında yer alan ispat etkinlik sayılarının aynı doğrultuda olmadığını yani ispat etkinliklerinin yetersiz olduğunu belirtmiştir. Ülkemizde ders kitaplarındaki ispat etkinliklerini inceleyen az sayıda çalışmanın olması bu konuya yönelik daha fazla çalışma yapılmasını zorunlu kılmaktadır.

Bu çalışmanın amacı, 2013 ve 2018 yıllarında yapılan öğretim programlarındaki değişiklikler doğrultusunda yayımlanmış olan ortaokul 7. ve 8. sınıf matematik ders kitaplarında yer alan geometri ve ölçme öğrenme alanına yönelik matematiksel ispat etkinliklerini Styliandes'in (2008) muhakeme ve ispat teorik çatısının matematik bileşenine göre incelemektir. Bunun yanında 2013 ve 2018 yıllarında ortaokul matematik öğretim programlarının genel hedefleri öğrencilerin matematiksel düşüncelerini mantıklı bir şekilde açıklamak, kendi akıl yürütmelerini kolaylıkla ifade edebilmek ve başkalarının akıl yürütmelerindeki eksiklikleri fark edebilmek olduğu dile getirilmektedir. Genel hedeflerin öğrencilerin ispat ve muhakeme becerileri ile ilişkili olduğu söylenebilmektedir. Bu doğrultuda hedeflere uygun bir şekilde ders kitaplarında da ispat etkinliklerinin kullanım oranının değişip değişmediğini belirlemek bu çalışmanın bir diğer amacıdır. Bu doğrultuda çalışmanın problemi "2013 ve 2018 yıllarında okutulan 7. ve 8. sınıf matematik ders kitaplarında geometri ve ölçme alanında ne tür ispat etkinliklerine yer verilmiştir?" şeklindedir.

\section{Kuramsal Çerçeve}

Lakatos (1976) matematiksel bilginin belli aşamalar sonucunda oluştuğunu ifade etmektedir. Bu aşamalar,

- Anlamlı matematiksel örüntüler/ilişkiler bulma/düzenleme,

- Örüntüler yardımılla iddialar ortaya atma,

- Yeni kanıtlara karşılık bu iddiaları test etme,

- Olası karşı örneklere göre iddiaları düzenleme,

- Elde edilen ilişkilerin nasıl ve niçin olduğuna yönelik argümanlar/ispatlar sunma

şeklinde ifade edilmiştir (Davis ve Hersh, 1980, s.292). Stylianides (2008) matematiksel bilginin oluşumuyla ilgili aşamaları göz önüne alarak muhakeme ve ispat (reasoning-and-proving) adı altında bir teorik çatı oluşturmuştur. Stylianides (2008) oluşturduğu teorik çatının matematik ders kitapları ile öğrenme ve öğretme faaliyetlerinin incelenmesinde kullanılabileceğini belirtmektedir. Stylianides (2008) teorik çatısının matematiksel, psikolojik ve pedagojik olmak üzere üç bileşenden oluştuğunu ifade etmektedir. Bu çalışmada bu teorik çatının sadece matematik bileşeni göz önüne alınmıştır. Stylianides (2008) muhakeme ve ispat teorik çatısının matematik bileşenini matematiksel genellemeler yapma ve matematiksel iddialara destek sağlama şeklinde iki kısımda ele almıştır (Tablo 1).

Tablo 1. Stylianides'in (2008) Muhakeme ve İspat Teorik Çatısının Matematik Bileşeni

\begin{tabular}{|c|c|c|c|}
\hline \multicolumn{4}{|c|}{ Muhakeme ve İspat } \\
\hline \multicolumn{2}{|c|}{ Matematiksel Genellemeler Yapma } & \multicolumn{2}{|c|}{ Matematiksel İddialara Destek Sağlama } \\
\hline Örüntü belirleme & Varsayım oluşturma & İspat yapma & $\begin{array}{l}\text { İspat olmayan bir } \\
\text { argüman sunma }\end{array}$ \\
\hline $\begin{array}{ll}\text { - } & \text { Olası örüntü } \\
\text { - } & \text { Kesin örüntü }\end{array}$ & - Varsayım & $\begin{array}{c}\text { - Genellenebilir } \\
\text { örnek } \\
\text { - Gösterim }\end{array}$ & $\begin{array}{l}\text { - Empirik argüman } \\
\text { - Rasyonel }\end{array}$ \\
\hline
\end{tabular}

Tablo 1'e göre Stylianides (2008) matematiksel genellemeler yapmayı örüntü belirleme ve varsayım oluşturma şeklinde ikiye ayırmaktadır. Ayrıca örüntü belirlemeyi de olası örüntü ve kesin örüntü şeklinde iki kısımda incelemektedir. Stylianides (2008) kuralı kesin ve tek/belli olan örüntüyü kesin örüntü ve kuralı tek olmayan ve birden fazla kuralı bulunabilecek örüntüyü ise olası örüntü şeklinde tanımlamaktadır. Örneğin, 2, 4, 6, .. , 2n, ... şeklindeki bir örüntü kuralı belli olan ve çift doğal sayıları gösteren kesin bir örüntü iken $2,4, \ldots$ şeklinde yazılan bir örüntü olası bir örüntü olarak ifade edilebilir. Çünkü bu örüntüde 4 'ten sonra 6' da gelebilir ya da daha farklı bir sayı da gelebilir. Benzer şekilde teorik çatıda yer alan varsayım kavramını ise tamamlanmamış bir ispatı temel alan genel 
matematiksel ilişkiler hakkındaki mantıklı hipotezler olarak ifade etmektedir. Varsayımlar oluşturma ve örüntü belirleme etkinlikleri birbirleri ile yakından ilişkili olsa da Stylianides (2008; s.11) bu iki kavram arasında iki önemli farklılıktan söz etmektedir. Bu farklılıklardan ilki, varsayım oluşturmada varsayımın oluşumuna neden olan durumlar kümesi için bir hipotez oluşturulur ve bu hipotez bu durumlar kümesinin ötesine kadar genişletilebilir. Ancak bu durum örüntü bulma için geçerli değildir. Örneğin farklı çevre uzunluğuna sahip dikdörtgenleri inceleyen bir öğrenci bu dikdörtgenlerin çevresi ile alanı arasında bir ilişki belirleyebilir ve bu ilişkiye dayanarak "dikdörtgenin çevresi arttıkça alanı da artar" varsayımını oluşturabilir. Hatta bu iddiasının sadece dikdörtgen için değil tüm dörtgenler için geçerli olduğunu da ifade edebilir. Bu şekilde varsayımını genişletebilir. İkincisi ise varsayım oluşturmada bir hipotez öne sürülür. Hâlbuki örüntü oluşturmada bir veri kümesine uyan ve doğruluğu hakkında şüphe bildirmeyen ilişkiler tanımlanır. Örneğin öğrenci "dikdörtgenin çevresi arttıkça alanı da artar" hipotezinin doğruluğunu ilişkide gözlemlese de karşı örneklerle bu varsayımın her zaman geçerli olmadığını belirleyebilir. Örneğin $2 \times 4$ şeklindeki bir dikdörtgenin alanı 8 br $^{2}$ ve çevresi ise 12 br'dir. Bu dikdörtgenin enini 1 br azaltıp, boyunu 2 br artırırsak dikdörtgen 1x6 şeklinde olur ki çevresi 14 br ve alanı ise 6 br $^{2}$ olur.

Stylianides (2008) teorik çatısında matematiksel iddialara destek sağlamayı ispat yapma ve ispat olmayan bir argüman sunma şeklinde iki kısımda ele almıştır. İspat yapma kendi içerisinde genellenebilir örnekler ve gösterim şeklinde ikiye ayrılmaktadır. Genellenebilir örnekler genel bir durumun temsilcisi olarak değerlendirilen belli bir durumu temel alan ispatlardır. Bir diyagram ya özel bir şekil üzerinde matematiksel bir durumun geçerliğinin gösterilmesi bu duruma bir örnek olarak verilebilir. Genellenebilir örnek ispatında, bir argüman matematiksel ilişkilerin bir durumu üzerine inşa edilir ve daha sonra bu gibi tüm durumlara genelleştirilir. Genellenebilir örneğin tersine gösterim ise belli bir olayın temsiline dayanmayan ispatlardır. Karşıt örnekler, çelişki bulma ve tümevarım ile ispatlar gösterim örnekleri olarak verilebilir. Stylianides (2008) teorik çatısında ispat olmayan bir argüman sunma bileşenini de empirik argüman ve rasyonel şekilde iki bölüme ayırmaktadır. Empirik argüman matematiksel iddianın doğruluğu için ikna edici olmayan kanıtlar sunan bir argüman olarak tanımlanabilir. Yani, empirik argümanda iddianın doğruluğu için matematiksel ispat yerine, iddianın olası durumlar için doğruluğunun kontrol edilmesine ve buradan iddianın doğru olabileceği sonucuna ulaşılması söz konusudur. Rasyonel argüman ise ne bir ispattır ne de bir empirik argümandır. Eğer bir argüman kullandığı bazı temel kabul edilmiş gerçeklere belirgin atıfta bulunmuyor ise ya da belirli bir topluluğun kabul edilmiş gerçekler kümesine ait olmayan ifadeler kullanıyor ise rasyonel argüman olarak kabul edilebilir. Bu duruma yönelik Stylianides (2008) bir öğrencinin "tek sayı + tek sayı = çift sayı" ifadesinin doğruluğunu gösterirken henüz sınıftaki diğer öğrenciler tarafından doğruluğu onaylanmamış "çift sayı + çift sayı = çift sayı" durumunu kullanmasını örnek olarak vermektedir. Bu örneğe göre öğrenci "çift sayı + çift sayı = çift sayı" olduğundan iki tek sayının toplamını tek sayı + tek sayı $=($ çift say $1+1)+($ çift sayı +1$)=$ çift sayı + 2 = çift sayı şeklinde bir açıklama yapabilir. Bu açıklama Stylianides'e (2008) göre rasyonel bir argüman olarak kabul edilmektedir.

\section{YÖNTEM}

Bu araştırmada 2013 ve 2018 matematik öğretim programlarına göre hazırlanan dört matematik ders kitabındaki ispat etkinlikleri incelenmiştir. Ders kitapları MEB'e bağlı devlet okullarında kullanılan kitaplardan seçilmiştir. Bu bağlamda çalışmanın yöntemi doküman incelemesidir. Doküman incelemesi nitel araştırma yöntemlerinden biri olup araştırılması gereken olgular hakkında bilgi içeren yazılı materyallerin kullanılarak araştırmacının gözlem veya görüşme yapmadan bilgi edinmesini sağlayan bir yöntemdir (Şimşek ve Yıldırım, 2018).

\section{Çalışma Grubu}

Araştırmanın çalışma grubunu 2013 yılı matematik öğretim programına göre hazırlanan 7. sınıf matematik ders kitabı (Keskin, 2016) ile 8. sınıf matematik ders kitabı (Aydın, 2016) ve 2018 matematik öğretim programına göre hazırlanan 7. sınıf matematik ders kitabı (Altıntaş ve Keskin, 2019) ile 8. sınıf matematik ders kitabı (Atmaz ve Serfiçeli, 2019) oluşturmaktadır. İncelenen kitaplar Sivas ili bölgesinde okutulmuş olan 7. ve 8. sınıf matematik ders 
kitaplarıdır. Bu araştırmanın amacı, matematik öğretim programında yapılan güncellemeler sonucu hazırlanmış ders kitaplarındaki ispat etkinliklerini incelemek olduğu için öğretim programında güncellemelerin yapıldığı 2013 ve 2018 matematik öğretim programlarına göre hazırlanan ders kitapları seçilmiştir. Bunun yanında ortaokul matematiğinde ispat etkinliklerine daha fazla yer verilen öğrenme alanlarından biri geometri ve ölçme alanı olduğu için ders kitaplarında bu öğrenme alanında yer alan etkinliklere odaklanılmışır.

\section{Veri Analizi}

2013 ve 2018 müfredat değişikliklerine göre yayımlanan ortaokul 7. ve 8. sınıf matematik ders kitapları Stylianides'in (2008) Muhakeme ve İspat Teorik Çatısının Matematik Bileşeni çerçevesi doğrultusunda analiz edilmiştir.

Ders kitaplarını inceleme süreci iki aşamada gerçekleştirilmiştir. İlk olarak ders kitapları genel olarak incelenmiş ve kitapların giriş, gelişme ve sonuç bölümlerinin bulunduğu bir düzene sahip oldukları belirlenmiştir. Bu bölümlerde öğrencilere önceki bilgilerini hatırlatma amaçlı bilgilere ya da konu hakkında temel bilgilerin ve açıklamaların örneklerle ve etkinliklerle pekiştirildiği uygulamalara ve son olarak da değerlendirme etkinliklerine yer verildiği belirlenmiştir. Bir sonraki adımda örnek, etkinlik, problem çözme/kurma, derse hazırlık ve değerlendirme sorularının belirlenmesi için bir inceleme yapılmıştır. Ders kitaplarında sınıflandırma yaparken öğrencilerin süreç içerisinde aktif oldukları problem çözme/kurma, etkinlik ve örnekler üzerinde durularak bu matematiksel çalışmalardaki ispat etkinlikleri incelenmiştir. Buna karşın ders kitaplarında yer alan alıştırma ve ödevler ise daha çok çoktan seçmeli sorulardan oluştuğu için değerlendirmeye alınmamıştır. Ayrıca derse hazırlık kısımları da öğrencinin konu hakkında dikkatini çekerek onu derse hazırlamak amacı ile oluşturulmuş aktivitelerden oluştuğu için benzer şekilde değerlendirmeye alınmamıştır. Analizler, kuramsal çerçeve kapsamında problemler, örnekler ve etkinlikler üzerinden yapılmıştır. İncelenen dört kitap içerisinde araştırmanın amacı göz önüne alınarak içerisinde ispat etkinliklerine yer vermeyen aktiviteler incelemeye dâhil edilmemiştir. Bu nedenle ders kitapları incelenirken örnek, etkinlik ve problem olmak üzere üç temel aktivite üzerinde durulmuştur.

Çalışmanın veri analizi güvenirliğini sağlamak için ispat ve muhakeme süreçleri konusunda yurt içi ve yurt dışı literatüre hâkim olan alanında uzman bir akademisyenden görüş alınmıştır. Yani verilerin başka bir kodlayıcı tarafından da kodlanması sağlanmıştır. Bir etkinlik durumunun Stylianides'in (2008) çerçevesine göre hangi sınıfa ait olduğuna karar verirken ilk önce o ispat sınıfının açıklaması tekrardan incelenmiş ve o sınıfa uygun diğer örnekler değerlendirilmiş daha sonra etkinliğin analitik çerçevede yer alan hangi sınıfa uygun olduğuna karar verilmiştir. Örneğin Stylianides (2008) bir argüman bazı kabul edilmiş doğrulardan söz etmiyor ya da kabul edilmiş doğrulardan oluşan kümeye ait olmayan ifadelere yer veriyorsa bu argümanı rasyonel argüman olarak tanımlamıştır. Bu tanımlamaya göre Şekil 1'deki etkinlik rasyonel argüman olarak sınıflandırılmıştır.

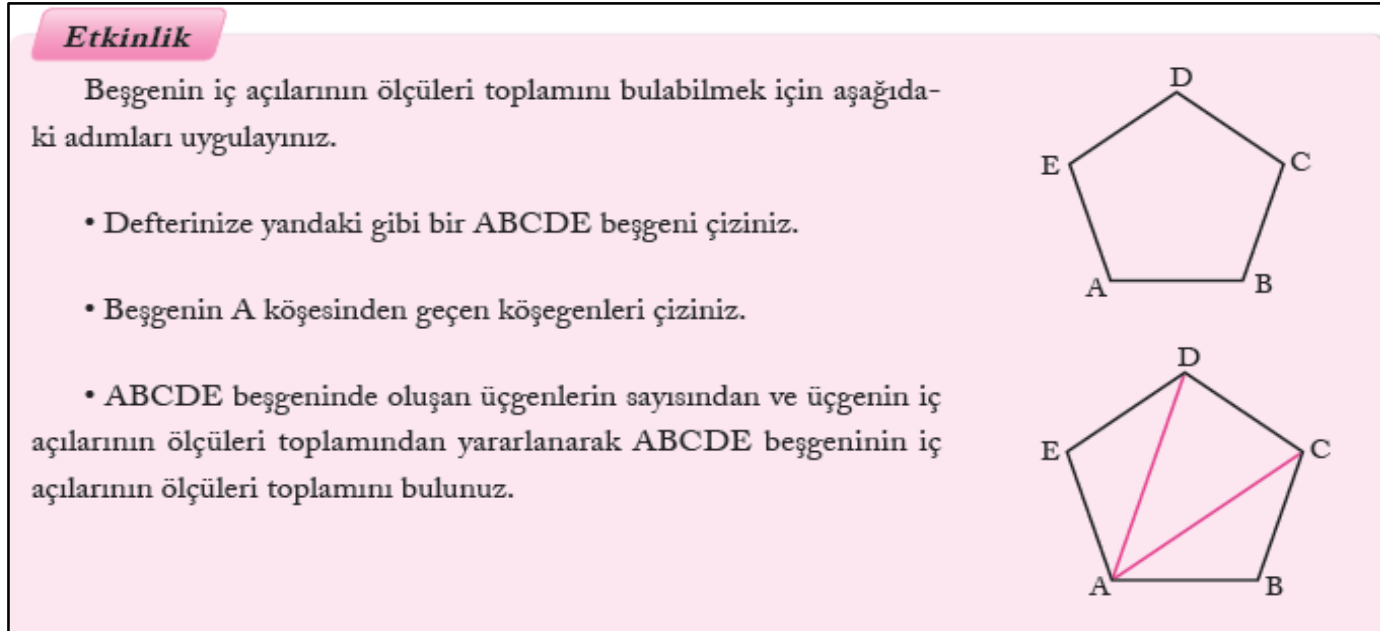

Şekil 1. 2017 yılında yayımlanmış 7. sınıf matematik ders kitabında yer alan rasyonel argüman gösterimi 
Şekil 1'deki etkinlikte öğrencilerden bir beşgen ve bu beşgenin bir köşesine ait köşegenleri çizmeleri istenmektedir. Burada öğrencilerden beşgen içerisinde oluşan üçgen sayısı ile her bir üçgenin iç açılarının ölçüleri toplamını göz önüne alarak beşgenin iç açılarının ölçüleri toplamını belirlemeleri beklenmektedir. Ancak öğrencilerden köşegen çizilen köşenin beşgenin herhangi bir köşesi olması durumunda da sonucun geçerli olduğunu açıklamaları beklenmemektedir. Ayrıca, çizimi verilen beşgen düzgün bir beşgendir ve yapılan işlem bu şekil ile ilişkilendirilmiştir. Oysa etkinliğin giriş ve sonuç kısımlarında herhangi bir beşgen için iç açıların ölçüleri toplamının bulunması ifade edilmektedir. Bu sebeplerden dolayı bu etkinlik rasyonel etkinlik olarak kodlanmıştır.

\section{BULGULAR}

Bu kısımda ilk olarak ders kitaplarında yer alan çalışmaları ispat çerçevesi kapsamında incelenmeden önce daha ayrıntılı bir analiz yapılabilmesi için genel bir inceleme yapılmıştır ve kitaplarda kullanılan örnek, problem ve etkinlik sayıları belirlenmiştir. Ders kitaplarının genel incelemesi doğrultusunda dört kitapta geometri ve ölçme alanlarında yer alan örnek, etkinlik ve problem sayıları Şekil 2'de gösterilmiştir.

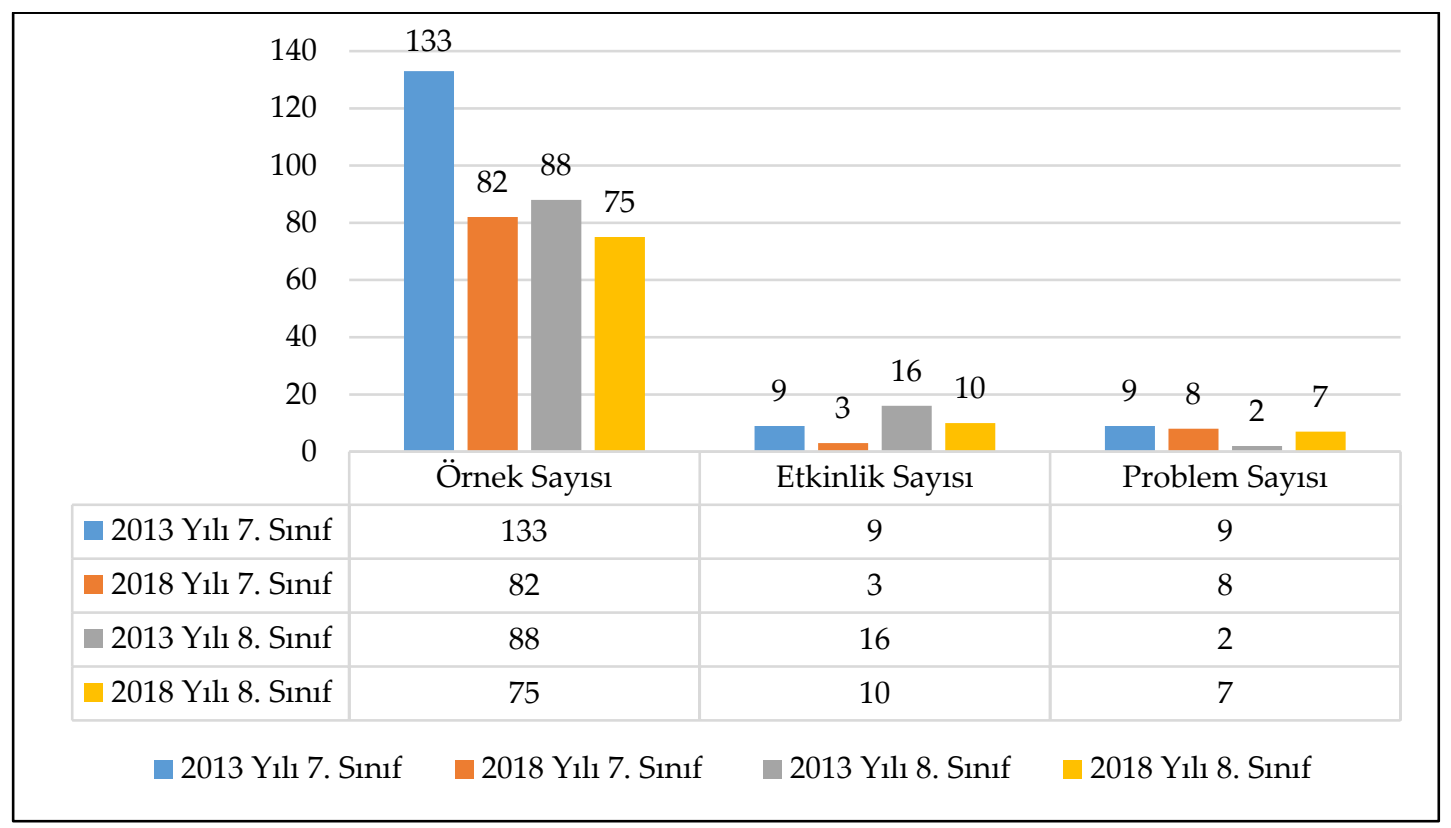

Şekil 2. Ders kitaplarında geometri ve ölçme öğrenme alanında kullanılan örnek, problem ve etkinlik sayıları

Şekil 2'de ders kitaplarında yer alan toplam 442 aktiviteden 378(\%85,52) aktivitenin örneklerden, 38 (\%8,59) aktivitenin etkinliklerden ve $26(\% 5,88)$ aktivitenin ise problemlerden oluştuğu görülmektedir. Bunun yanında 2013 yılındaki ortaokul matematik öğretim programı temel alınarak hazırlanan 7. Sınıf matematik ders kitabında toplam 151 aktivite yer almaktadır. Bu aktivitelerin $133(\% 88,07)$ tanesi örneklerden, $9(\% 5,96)$ tanesi ise etkinliklerden ve 9 $(\% 5,96)$ tanesi de problemlerden oluşmaktadır. 2013 yılındaki ortaokul matematik öğretim programı temel alınarak hazırlanan 8. sınıf matematik ders kitabında ise106 tane aktiviteye ver verildiği tespit edilmiştir. Bu aktivitelerden $88(\% 83,01)$ tanesinin örneklerden, $16(\% 15,09)$ aktivitenin etkinliklerden ve $2(\% 1,88)$ aktivitenin ise problem çözmeden oluştuğu görülmektedir. 2018 yılındaki ortaokul matematik öğretim programına yönelik hazırlanan 7. sınıf matematik ders kitabına bakıldığında toplam 93adet aktiviteye yer verildiği ve bunlardan $82(\% 88,17)$ aktivitenin örneklerden, $3(\% 3,22)$ aktivitenin etkinliklerden ve $8(\% 8,6)$ aktivitenin ise problem çözmeden oluştuğu görülmektedir. Son olarak 2018 yılındaki ortaokul matematik öğretim programına göre hazırlanan 8. sınıf matematik ders kitabında ise toplam 92 adet aktiviteye yer verildiğinin ve bunlardan 75 (\%81,52) aktivitenin örneklerden, 10 $(\% 1,08)$ aktivitenin etkinliklerden ve $7(\% 7,6)$ aktivitenin ise problem çözmeden oluştuğu görülmektedir. Genel inceleme sonucunda ders kitaplarında geometri ve ölçme alanında yer alan çalışmaların sayısına ulaşılarak ne kadarının ispat etkinliği olarak değerlendirilebileceği yönünde bir sonuç elde edilmek istenmektedir. Bu doğrultuda genel inceleme ve ispat etkinlikleri açısından yapılan incelemeler sonucunda elde edilen veriler arasında değerlendirme yapılabilecektir. 
2013 ve 2018 ortaokul matematik öğretim programlarına göre hazırlanan 7. ve 8. sınıf matematik ders kitaplarında geometri ve ölçme alanına yönelik ispat etkinliklerinin dağılımı Şekil 3'tesunulmuştur.

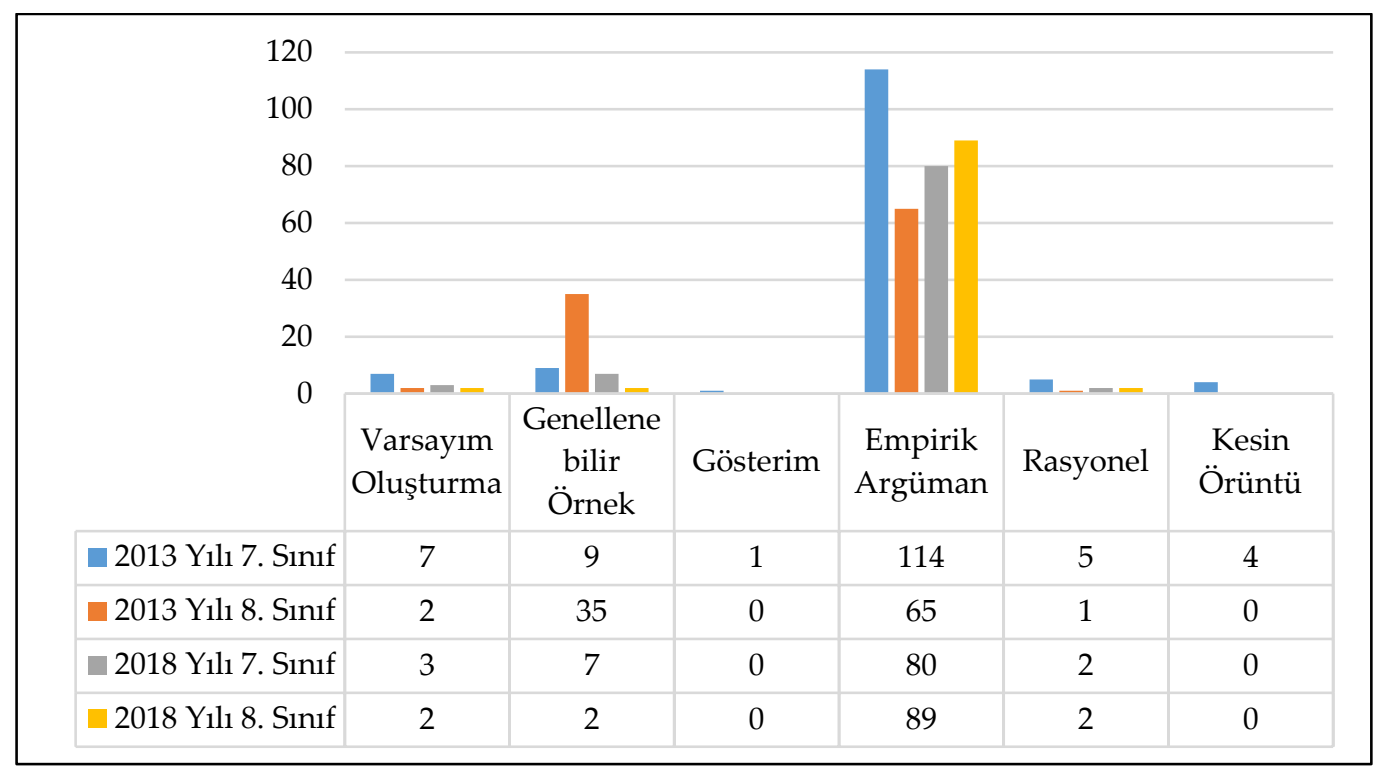

Şekil 3. 2013 ve 2018 yılında yayımlanan 7. ve 8. sınıf matematik ders kitaplarında geometri ve ölçme alanına yönelik ispat etkinliklerinin dağılımı

Şekil 3'egöre 2013 yılındaki 7. sınıf matematik ders kitabında geometri ve ölçme öğrenme alanı içerisinde 7 varsayım oluşturma, 9 genellenebilir örnek, 1 gösterim, 5rasyonel, 4 kesin örüntüye 114empirikargüman şeklinde ifade yer alırken, 2018 yılında yayımlanan 7. sınıf matematik ders kitabında ise 3 varsayım oluşturma, 7 genellenebilir örnek, 2 rasyonel ve 80empirik argüman şeklinde ifade yer almaktadır. Benzer şekilde 2018 yılındaki 8. sınıf matematik ders kitabında geometri ve ölçme öğrenme alanı içerisinde 2 varsayım oluşturma, 2 genellenebilir örnek, 2 rasyonel ve 89empirikargüman şeklinde ifade yer alırken, 2013 yılında yayımlanan 8. sınıf matematik ders kitabında ise 2 varsayım oluşturma, 35genellenebilir örnek 65empirik argüman ve 1 rasyonel argüman şeklinde ifade yer almaktadır. Kuramsal çerçeve doğrultusunda belirlenen kodlar doğrultusunda yapılan analize ilişkin örneklerden birkaçı sınıflandırmanın nasıl yapıldığına açıklık getirmek için sunulmuştur. Şekil 4'te 2018 yılında yayımlanmış 7. sınıf matematik ders kitabında yer alan bir genellenebilir örnek ispatı yer almaktadır.

\section{4. Örnek}

Düzgün sekizgenin bir iç açısını ölçüsünü bulalım.

\section{Çözüm}

Sekizgenin iç açılarının ölçüleri toplamı

$(\mathrm{n}-2) \cdot 180^{\circ}=(8-2) \cdot 180^{\circ}$

$$
=6 \cdot 180^{\circ}
$$$$
=1080^{\circ} \mathrm{dir} \text {. }
$$

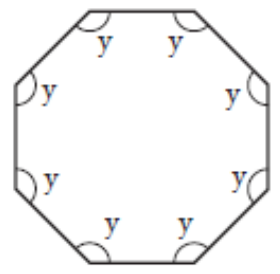

Düzgün sekizgenin iç açılarının ölçüleri birbirine eşittir. Düzgün sekizgenin iç açılarının ölçülerinin her birini y olarak alalım. Bu durumda $y+y+y+y+y+y+y+y=1080^{\circ}$

$$
\begin{aligned}
\frac{8 y}{8} & =\frac{1080}{8_{1}} \\
y & =135^{\circ} \text { bulunur. }
\end{aligned}
$$

Şekil 4. 2018 yılında yayımlanmış 7. sınıf matematik ders kitabında yer alan genellenebilir örnek

Bu örnek Stylianides (2008) teorik çatısına göre genellenebilir bir örnek kategorisindedir. Çünkü düzgün çokgenlerin iç açıları ölçüleri toplamının kenar sayısına bölünmesi ile çokgenin bir iç açısına ulaşılmaktadır. (n2).180/n şeklinde ifade edilen formüle bu örnek sonucunda ulaşılmıştır. Bu durum diğer düzgün çokgenlere de 
genellenebilir olduğu için örnek genellenebilir örnek olarak kodlanmıştır. 7. sınıf ders kitabından alınan bu örnekteki duruma benzer özelliklere sahip diğer ders kitaplarında yer alan çalışmalar da genellenebilir örnek olarak kodlanmıştır. 2013 yılında yayımlanan 7. sınıf matematik ders kitabında yer alan rasyonel argüman kategorisindeki ispat örneği ise Şekil 5 'te sunulmuştur.

\section{1. ÖRNEK}

Yandaki şekilde 2. şeklin, 1. şeklin kaç birim ơtelenmiş hâli olduğunu bularak iki şeklin eş olup olmadığını belirtelim.

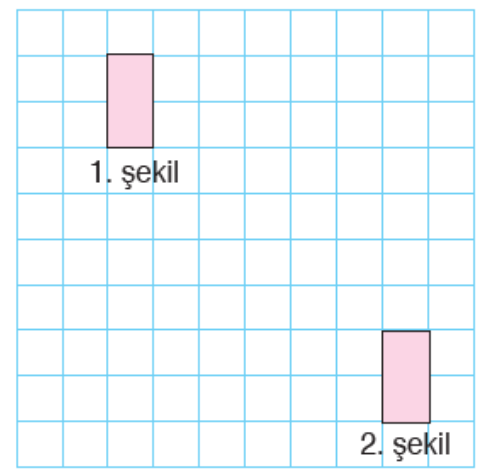

\section{ÇözüM}

2. şekil, 1. şeklin 6 birim sağa, 6 birim aşağı otelenmiş hâlidir. Buradaki 1. şekil ile 2. şekil birbirine eş şekillerdir.

1. şekil, konum değiştirerek 2. şeklin konumuna ơtelenmiştir. Şekillerin büyäklükleri değişmemiştir.

Şekil 5. 2013 yılında yayımlanan 7. sınıf ders kitabında yer alan rasyonel argüman gösterimi

Bu örnekte öğrencilere öteleme sonucunda elde ettikleri şekil ile baştaki şeklin eş olup olmadığı sorulmuştur. Öğrencilerden şekillerin neden birbirine eş olduğuna dair bir açıklama yapmaları beklenmemiştir. Öteleme sonucunda elde edilen şekil ile başlangıçtaki şeklin büyüklükleri ile ilgili işlemlere de yer verilmemiştir. Yani bu şekillerin kenar uzunlukları ve alanlarının değişmediğini göstermeye yönelik bilgilere yer verilmemiştir. Bu nedenle bu örnek rasyonel argüman olarak sınıflandırılmıştır.

2018 yılında yayımlanan 8. sınıf matematik ders kitabında yer alan varsayım oluşturma kategorisine yönelik bir gösterim Şekil 6'dasunulmuştur.

Eraç ve Gereç: $20 \mathrm{~cm}$ uzunluğunda tel
- Telı, aşağıda ölçüleri verilen uzunluklarda bükerek üçgen oluşturmaya çalışınız.
$8 \mathrm{~cm}, 6 \mathrm{~cm}, 6 \mathrm{~cm} \quad 7 \mathrm{~cm}, 5 \mathrm{~cm}, 8 \mathrm{~cm} \quad 2 \mathrm{~cm}, 10 \mathrm{~cm}, 8 \mathrm{~cm}$
$3 \mathrm{~cm}, 5 \mathrm{~cm}, 12 \mathrm{~cm} \quad 10 \mathrm{~cm}, 5 \mathrm{~cm}, 5 \mathrm{~cm} \quad 9 \mathrm{~cm}, 6 \mathrm{~cm}, 5 \mathrm{~cm}$
$\checkmark$ Hangi kenar uzunluklarıyla üçgen oluşturabildınız? Neden?
$\checkmark$ Hangi kenar uzunluklarıyla üçgen oluşturamadınız? Neden?
Sız de bu telle kenar uzunluklarını belirlediğiniz üçgenleri oluşturmaya çalışınız. Oluştur-
maya çalıştığınız üçgenin kenar uzunluklarını yazınız.
$\checkmark$ Oluşturduğunuz üçgenlerin Ikı kenar uzunluğunun toplamı veya farkının mutlak de-
ğgerı Ile üçüncū kenarın uzunluğu arasında nasıl bir ilişkı vardır?

Şekil 6. 2018 yılında yayımlanan 8. sınıf matematik ders kitabında yer alan varsayım oluşturma gösterimi

Şekil 6' daverilen etkinlikte öğrencilerden farklı uzunluklara sahip telleri kullanarak hangi durumlarda üçgen oluştuğunu fark etmeleri beklenmektedir. Etkinlikte sunulan belirli durumlar gözlemlenerek bir genellemeye ulaşılması amaçlandığı için varsayım oluşturma kategorisinde sınıflandırılmıştır.

|Manisa Celal Bayar University Journal of The Faculty of Education, 2021, Vol. 9, No. 1 | 
Şekil 7'deise 2013 yılında yayımlanan 7. sınıf ders kitabında yer alan ve rasyonel argüman durumu olarak sinıflandırılan bir örnek görülmektedir.

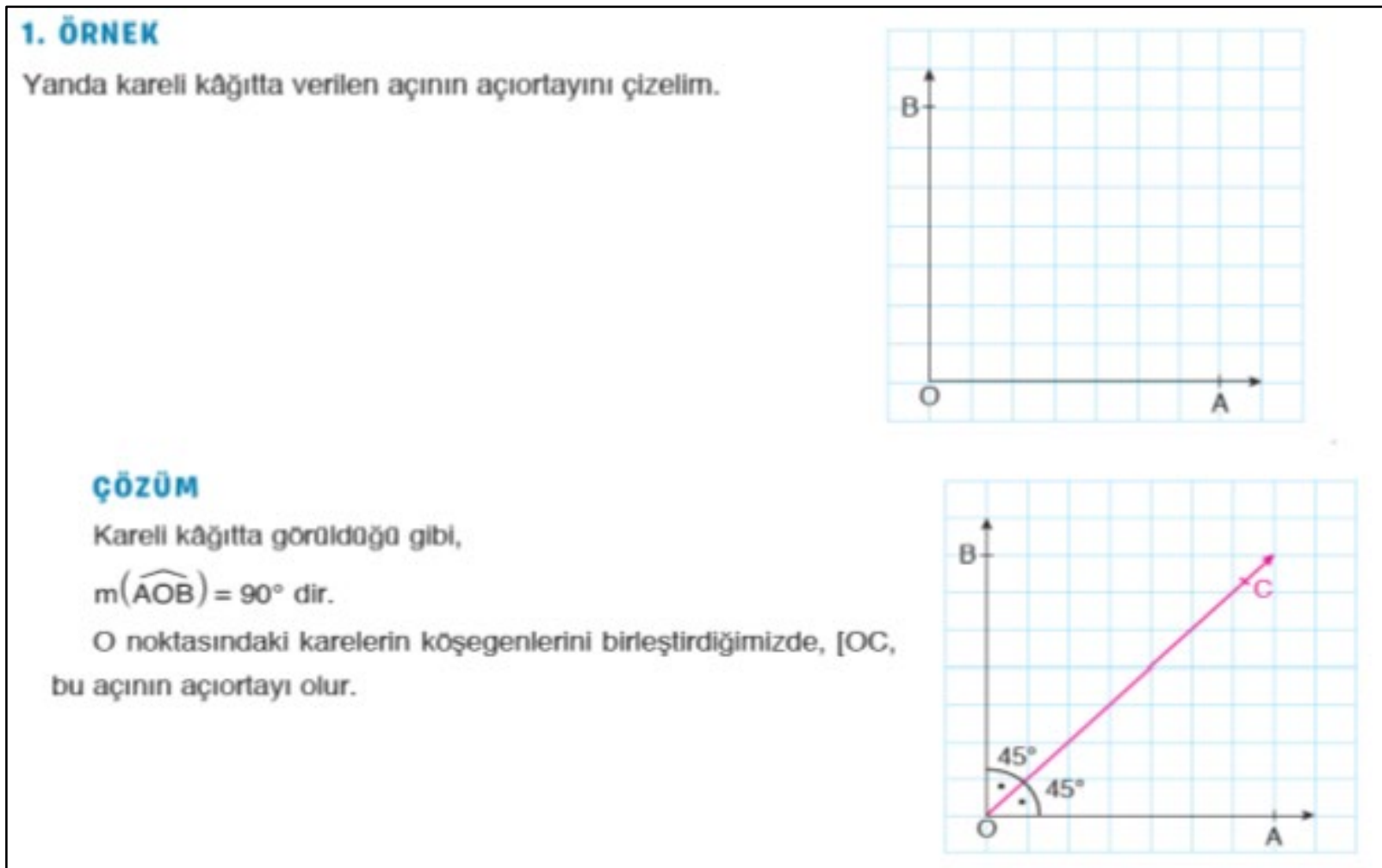

Şekil 7. 2013 yılında yayımlanan 7. sınıf matematik ders kitabında yer alan rasyonel gösterimi

Şekil 7'deverilen örnekte bir dik açının açıortayının çizilişi öğrencilere gösterilmektedir. Ancak burada öğrencilere karenin köşegeninin niçin açıortay oluşturduğu açıklanmamaktadır. Ayrıca bu durum sadece dik açı için geçerli bir durumdur ve diğer açılar ile ilişkisine değinilmemiştir. Bu sebeplerden dolayı rasyonel argüman olarak sınıflandırılmıştır. Şekil 8'de ise 2013 yılında yayımlanan 7. sınıf ders kitabında yer alan kesin örüntü örneği sunulmuştur.

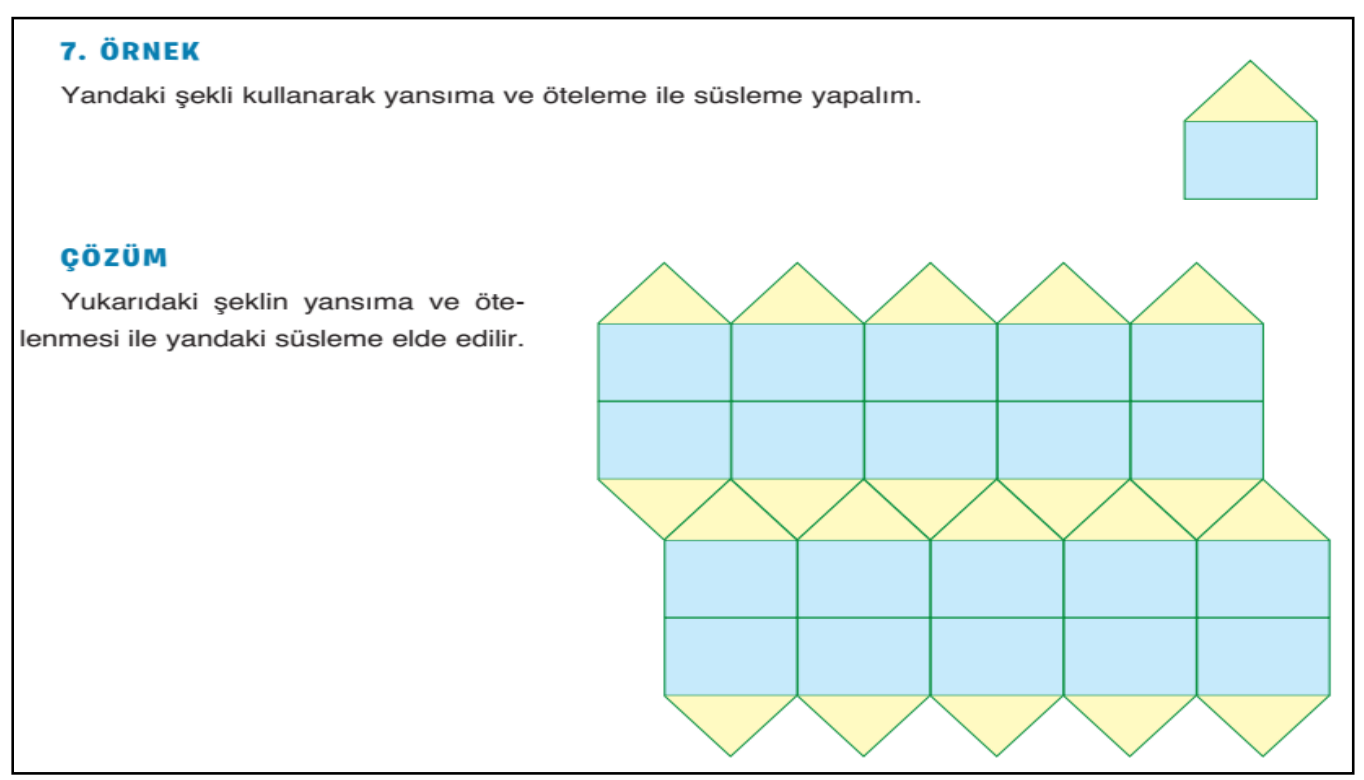

Şekil 8. 2013 yılında yayımlanan 7. sınıf matematik ders kitabında yer alan kesin örüntü gösterimi

Şekil 8'de yer alan örnekte belirli bir kurala göre oluşturulmuş bir sonraki adımda hangi şeklin geleceğinin bilindiği bir süsleme örüntü yardımı ile oluşturulmuştur. Bir sonraki adımda hangi işlemin uygulanacağı açı net olduğu için bu örüntü kesin örüntü olarak sınıflandırılmıştır. 7. sınıf ders kitabından alınan bu örnekteki duruma 
benzer özelliklere sahip diğer ders kitaplarında yer alan çalışmalar da kesin örüntü olarak kodlanmıştır. Son olarak ise şekil 9'da 2013 yılında yayımlanan 7. sınıf ders kitabında yer alan gösterim örneği sunulmuştur.

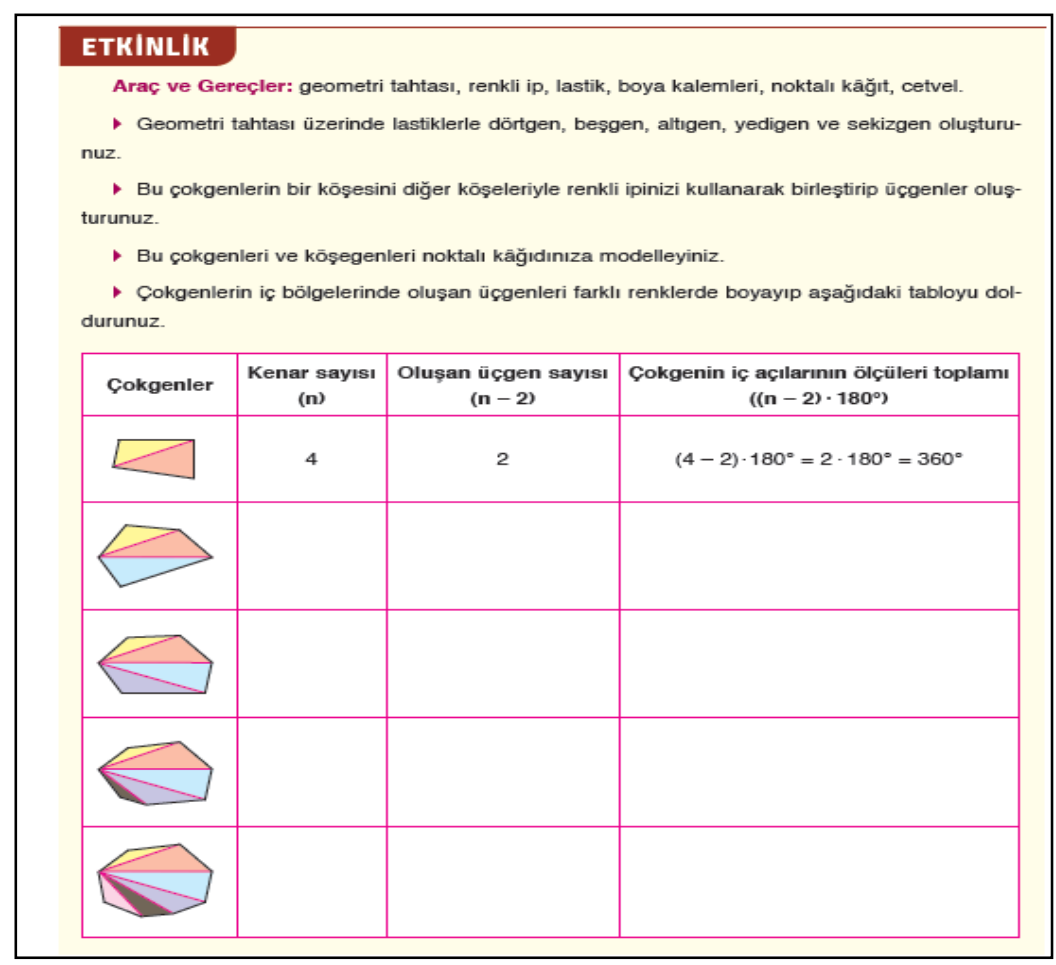

Şekil 9. 2013 yılında yayımlanan 7. sınıf matematik ders kitabında yer alan gösterim örneği

Şekil 9'daki etkinlikte öğrenciler köşegen çizilebilecek en az kenarlı çokgenden başlayarak n kenarlı bir çokgene genelleme yapmaktadır. Bu durum ise ispat çerçevesinde yer alan gösterim türünün özelliklerini yansıtmaktadır. Karşıt örnek gösterme, çelişki bulma ve tümevarım ile yapılan ispatların gösterim türüne uygun olacağını belirtmiştir. Yukarıda verilen etkinlik de tümevarım olarak değerlendirilebilecek özelliktedir. Bu nedenle etkinlik gösterim olarak kodlanmıştır.

\section{TARTIŞMA}

Elde edilen bulgular2018 yılında yayımlanan 7. ve 8. sınıf matematik ders kitaplarında geometri ve ölçme alanında incelenen problem, örnek ve etkinlik sayılarının 2013 yılında yayımlanan 7. ve 8. sınıf matematik ders kitaplarındaki problem, örnek ve etkinlik sayılarından daha az olduğunu göstermektedir. Bu durumun bir nedeni öğretim programlarında yapılan revizyon çalışmaları dahilinde konu ve kazanımlarda yapılan sadeleştirmeler olabilir. Beyindi (2018), 2013 ve 2018 matematik öğretim programlarının karşılaştırmasını yaptığı incelemede2018 yılında güncellenen matematik öğretim programı ile ortaokul düzeyindeki matematik konularında sadeleştirmeye gidildiğini ve kazanım sayısının 233'ten 215'e düşürüldügünü belirtmiştir. Bunun yanında hem 2013 yılında hem de 2018 yılında yayımlanan ortaokul matematik öğretim programlarında öğrencilerin matematiksel muhakeme becerilerinin geliştirilmesinin önemi vurgulanmaktadır. İki program karşılaştırıldığında öğrencilerin kendi fikirlerini mantıklı bir şekilde açıklamaları ve arkadaşlarının fikirlerindeki eksiklikleri belirleyebilmelerinin önemi 2018 yılında matematik dersinin özel hedefleri içerisinde daha çok ön plana çıkmaktadır. Öğretim programında yapılan sadeleştirme ile beraber kitaplarda yer alan etkinlik, örnek ve problem sayısında da bir azalış olmuş ve bundan dolayı da ispat etkinliklerinin sayısını azaldığı söylenebilir. Bu duruma ek olarak kuramsal çerçevede yer alan ispat türlerinin çeşitliliğinde gözlenen azalış matematik öğretim programlarının hedefleri ile örtüşmemektedir. Benzer şekilde alan yazında Doğan (2019), Zeybek ve arkadaşları (2018) ile Stacey ve Vincent (2009) çalışmalarında ders kitaplarında yer alan ispat içeren örnek, etkinlik ve problem sayılarının hem yeterli sayıda hem de yeterli düzeyde olmadığını ifade etmektedir. Stacey ve Vincent (2009) inceledikleri 8. sınıf ders kitaplarındaki açılamaların genel olarak çok kısa olduğunu ve muhakeme becerilerinin temel yönlerini yansıtmadığını ifade etmiştir. Buna ek 
olarak yine aynı çalışmada ispat etkinliklerindeki çeşitliliğin incelenen kitaplara göre değil konulara göre farklılaştığını belirtmiş̧tir. Bu durum gösterim, rasyonel ve iddia ispat kodlarına sadece 2013 yılında yayımlanmış 7. sınıf ders kitabında rastlanması ve bu kodların çok az sayıda bulunmasının sebebi olarak 2018 yılında öğretim programında yapılan sadeleştirme ile konulardaki azalış doğrultusunda ispat türlerinde de azalış meydana gelmesi fikri ile paralellik göstermektedir. Benzer bir durumu Doğan (2019) ortaokul 8. sinıf ders kitaplarında ispat becerisi gerektiren çalışmaların istenilen düzeyde olmadığını belirtmiştir.

Ders kitaplarında yer alan etkinlik, örnek ve problem sayılarının azalmasının bir diğer nedeni de ders kitaplarının hazırlanmasında yaşanan yetersizlikler olabilir. Burada ifade edilmek istenen durum ders kitaplarında konu ile ilgili temel bilgilerin girişte öğrenciye hazır bir şekilde verilmesi ve peşinden öğrenciye çözümlü örneklerin, problem kurma yerine çözümlü problemlerin ve direkt bilgi uygulama etkinliklerinin sunulmasıdır. Bu bağlamda ders kitaplarında yer alan çalışmalar öğrencinin kendi düşüncelerini ve açıklamalarını keşfetmelerine pek imkân sağlamamaktadır ve bu durum özellikle öğretmenler tarafından olumsuz karşılanmaktadır. Korkmaz, Tutak ve İlhan (2020) matematik öğretmenlerinin ders kitapları hakkında görüşlerini aldığı çalışmasında öğretmenlerin ders kitaplarının içeriklerinin sorunlu ve ders kitaplarında yer alan örnek ve problemlerin ise yetersiz olduğunu ifade ettiklerini belirlemiştir.

Elde edilen sonuçlar ders kitaplarında en fazla örneklerin en az ise problemlerin yer aldığını göstermektedir. Problem türlerinde ise geometri ve ölçme konularında daha çok çözümlü problemlerin kural uygulama şeklinde sunulduğu görülmektedir. Bu durumun hem 2013 hem de 2018 yıllarında yayımlanmış tüm ders kitaplarında geçerli olduğu belirlenmiştir. Oysaki problem çözme becerileri yüksek bireylerin yetiştirilmesi gerektiği MEB (2013) ve MEB (2018) matematik öğretim programlarında vurgulanmaktadır. Çalışmada elde edilen bulgulara karşın İncikabı ve Tjoe (2013) Türkiye ve Amerika' da okutulan 6. ve 7. sınıf matematik ders kitaplarındaki oran -orantı konusundaki problemleri inceledikleri çalışmalarında Türkiye'de okutulan matematik ders kitaplarında yer alan problemlerin Amerika'ya göre daha çok açıklamalara ve çözüm süreçlerine odaklandığını ifade etmektedirler. Türkiye'deki ders kitaplarında oran-orantı konusunda kullanılan problemler bilişsel basamaklardan uygulama ve muhakeme alanına daha çok vurgu yapmaktadır. Bu durumlar göz önüne alınarak İncikabı ve Tjoe (2013) ders kitaplarında öğrencileri düşündürecek ve mantıklı açıklamalarla muhakeme yapmalarını sağlayacak problemlere her konuda ve daha fazla yer verilmesi gerektiğini önermektedir.

Ders kitaplarında yer alan ispat etkinlikleri incelendiğinde en fazla empirik argüman kategorisinde örneklerin yer aldığı tespit edilmiştir. Empirik argüman olarak sınıflandırılan çalışmaların verilen bir kuralın olası başka bir durum üzerinde doğruluğu şeklinde olduğu görülmektedir. Benzer bir sonuca Zeybek ve arkadaşları (2018) ortaokul ders kitaplarında yaptıkları çalışmada ulaşmıştır ve ispat olmayan empirik argüman kategorisindeki etkinliklerin ders kitaplarında geniş yer tuttuğunu ifade etmiştir. Harel ve Sowder'a (1998) göre bir kuralın doğruluğunu göstermek için öğrencilere sunulan birkaç olası durum üzerinden göstermek kavram yanılgılarına sebep olabilmektedir (Akt. Zeybek vd., 2018)

2013 yılında yayımlanmış ders kitaplarında genellenebilir örnek sayılarının 2018 yılında yayımlanmış ders kitaplarındaki genellenebilir örnek sayısından fazla olduğu belirlenmiştir.2013 yılında yayımlanan 8. sınıf ders kitabına karşın diğer kitaplarda örnekler belirli bir kuralın özel uygulaması olarak kullanılmıştır. Oysaki 2013 yılındaki örneklerin çoğu genellenebilir örnek olarak değerlendirilmiştir ve burada öğrenciler konu ile ilgili kurallara verilen özel örnek üzerinden ulaşmaktadır. Çalışkan (2012) ders kitabında yer alan örneklerin pek çoğunun öğrencileri tek bir durum üzerinden genelleme yapmaya yönlendirdiğini bunun yerine birden fazla örnek üzerinden genelleme yapmak için sunulan örnek sayısının çok az olduğunu belirtmiştir. Bu durum genellenebilir örnek sayısındaki fazlalık ile paralellik göstermektedir. Benzer bir durumu Kula ve Ören-Vural (2019) ders kitaplarındaki örneklerin öğrencileri ezbere sevk ettiğini veya sınırlı örnekler üzerinden genel sonuçlar elde ettiklerini belirtmiştir. Bununla beraber öğrencilerin birkaç özel örnek ile genel kurallara ulaşmaları onların matematiksel ispatlar yaparken çeşitli yanılgılar oluşturmalarına ve ispat yaparken zorlanmalarına neden olabileceği belirtilmiştir (Harel ve Sowder, 1998; Knuth, Choppin ve Bieda, 2009). 
$\mathrm{Bu}$ çalışmada ders kitaplarında yer alan ispat etkinlikleri Stylianides'in (2008) teorik çatısına göre incelenmiştir. Buna göre incelenen ispat etkinlikleri ders kitabındaki sunuluş şekliyle sınıflandırılmıştır. Yani etkinlikler sınıflandırılırken sınıf içerisindeki pedagojik durumlar göz ardı edilmiştir. Sınıf için ortamlarda bir konunun öğrenciye sunulmasında ders kitapları ve farklı kaynakların yanında öğretmenlerin pedagojik alan bilgileri de etkilidir. Bu bağlamda incelenen etkinlikler Stylianides' in (2008) teorik çatısına göre sınıflandırılsa da gerçek sınıf ortamlarında bu etkinliklerin nasıl sunulacağı tamamen öğretmene bağlıdır. Bu bağlamda gerçek sınıf ortamında bu etkinliklerin ilgili teorik çatıya göre sınıflandırılmasında farklı durumlar ortaya çıkabilir. Bu nedenle bu durum bu çalışmanın bir sınırlılığını oluşturmaktadır.

\section{SONUÇ ve ÖNERILLER}

Bu araştırma sadece 7. ve 8. Sınıf ders kitaplarını müfredat değişikliği yapılan 2013 ve 2018 yıllarında ve geometri ve ölçme konularında incelemiştir. Ders kitaplarında yer alan çalışmalar belirlenen analitik çerçeve kapsamında incelenmiştir. Elde edilen veriler doğrultusunda çerçevede yer alan ispat türlerinin hepsine ders kitaplarında yer verilmediği görülmüştür. Tespit edilen ispat türlerinin sıklığı ise değişiklik göstermektedir. Elde edilen bulgular doğrultusunda özellikle ders kitaplarında rasyonel, iddia, gösterim ve kesin örüntü ispat sınıflarına çok az rastlanırken ağırlık olarak genellebilir örnekler ve empirik argümanlara rastlanmıştır. Olası örüntü çeşidine ise hiç rastlanmamıştır. Buna karşın sayıca üstün olan genellenebilir örnek ve empirik argüman türlerinin öğrencilerin ispat süreçlerini olumsuz etkileyebileceği tartı̧̧ma kısmında belirtilmiştir. Buna karşın ders kitaplarının hem öğretmenler hem de öğrenciler açısından öğretim ve öğrenme sürecindeki önemi düşünülerek ders kitapları inceleme çalışmalarının sayısı arttırılarak eksik yönler belirlenebilir. Yapılan çalışmanın sınırlılığı göz önüne alınarak çalışmaya benzer kitap inceleme çalışmaları farklı sınıf seviyelerinde, yıllarda ve öğrenme alanlarında yapılabilir. Bunun yanı sıra çalışmada geometri ve ölçme konuları içerisinde yer alan problem, örnek ve etkinlik aktiviteleri üzerinde durulduğu için başka bir çalışmada konu ile ilgili bütün öğrenme ve öğretme evreleri ayrıntılı bir şekilde analiz edilebilir. Bu çalışmada incelenen etkinlikler ders kitaplarından farklı bir şekilde gerçek sınıf ortamlarında sunulabilir. Bu durum bu çalışmanın bir sınırlılığını oluşturmaktadır. Bu nedenle ders kitaplarında yer alan ispat etkinliklerini öğretmenlerin gerçek sınıf ortamında nasıl kullandıkları ileriki çalışmalarda incelenebilir. 
KAYNAKÇA

Altıntaş, Ş. ve Keskin, C. (2019). Ortaokul ve imam hatip ortaokulu matematik 7. sınıf ders kitabı. Ankara: Ekoyay Eğitim Yayıncilik.

Altıntaş, E. ve İlgün, Ş. (2020). İlköğretim matematik öğretmen adaylarının matematiksel ispata yönelik görüşlerinin belirlenmesi: Kars örneklemi. Kastamonu Education Journal, 28(3), 1573-1582. https://doi.org/10.24106/kefdergi.70612

Atmaz, D. ve Serfiçeli, Z. (2019). Ortaokul ve imam hatip ortaokulu matematik 8. sınıf ders kitabı. Ankara: Kök-e Yayıncılık. Aydın, E. (2016). Ortaokul matematik 8. sinıf ders kitabı. Ankara: Sevgi Yayınları.

Beyindi, S. (2018). 2013 ve 2018 ortaokul matematik dersi öğretim programlarının karşılaştırılması. Birey ve Toplum Dergisi, 8(15), 117-200.

Bieda, K. N., Ji, X., Drwencke, J., \& Picard, A. (2014). Reasoning-and-proving opportunities in elementary mathematics textbooks. International Journal of Educational Research, 64, 71-80.

Cihan, F. ve Akkoç, H. (2020). Öğretmen adaylarının ispatla ilgili görüşlerinin geliştirilmesi: bir tasarım çalışması. Türk Bilgisayar v eMatematik Ĕ̆itimi Dergisi, 11(1), 280-311.

Davis, P.J., \& Hersh, R. (1980). The mathematical experience, Harmondsworth: Penguin.

Çalışkan, Ç. (2012). 8.sınıf öğrencilerinin matematik başarılarıyla ispat yapabilme seviyelerinin ilişkilendirilmesi. (Yayınlanmamış Yüksek Lisans Tezi). Uludağ Üniversitesi, Eğitim Bilimleri Enstitüsü, Bursa.

Yeşilyurt-Çetin, A. ve Dikici, R. (2020). Matematik öğretmeni adaylarının cebirsel ispat yapabilme durumlarının incelenmesi. Online Journal of Mathematics, Science and Technology Education (OJOMSTE), 1(1), 75- 85.

Dikici, R., Güler, G. ve Özdemir, E. (2012). Öğretmen adaylarının matematiksel tümevarım yoluyla ispat becerileri ve matematiksel ispat hakkındaki görüşleri. Kastamonu Ĕ̆itim Dergisi, 20(1), 219-236.

Doğan, M. F. (2018). Analyzing textbooks to teach proof related activities at middle school level. Proceedings of International Conference on Mathematics: "An İstanbul Meeting for World Mathematicians" Mini Symposium on Approximation Theory Mini Symposium on matheducation, 139-143.

Doğan, M. F. (2019). Sekizinci sınıf matematik ders kitabındaki matematiksel akıl yürütme ve ispatı öğrenme olanakları. İnönü Üniversitesi Ĕ̆itim Fakültesi Dergisi, 20(2), 601-618. https://doi.org/10,17679/inuefd.527243

Fujita, T., \& Jones, K. (2014). Reasoning-and-proving in geometry in school mathematics textbooks in Japan. International Journal of Educational Research, 64, 81-91.

Gökkurt, B., Deniz, D., Akgün, L. ve Soylu, Y. (2014). Matematik alanında ispat yapma süreci üzerine yapılmış bazı araştırmalardan bir derleme. Başkent University Journal of Education, 1(1), 55-63.

Harel, G., \& Sowder, L. (1998). Students' proof schemes: Results from exploratory studies. In A. Schoenfeld, J. Kaput, \& E. Dubinsky (Eds.), Research in collegiate mathematics education, III (pp. 234-283). Washington DC: Mathematical Association of America.

Hanna, G., \& de Bruyn, Y. (1999). Opportunity to learn proof in Ontario grade twelve mathematics texts. Ontario Mathematics Gazette, 37(4), 23-29.

Hanna, G. (2000). Proof, explanation and exploration: An overview. Educational Studies in Mathematics, 44, 5-23.

İncikabı, L., \& Tjoe, H. (2013). A comparative analysis of ratio and proportion problems in Turkish and the U.S. middle school mathematics textbooks. Ahi Evran University Journal of Kırşehir Education Faculty, 14(1), 1-15.

Kaplan, A., Doruk, M., Öztürk, M. ve Duran, M. (2016). Matematik ve matematik eğitimi öğrencilerinin matematiksel ispata yönelik görüşleri arasında fark var midır. Journal of Human Sciencies, 13(3), 6020-6037. https://doi.org/10.14687/jhs.v13i3.4327

Keskin, C. (2016). Ortaokul 7 matematik ders kitabı. Ankara: Ada Matbaacılık. 
Kılıçoğlu, E. (2020). Ortaokul matematik ders kitabı etkinliklerinde soyutlama becerisinin incelenmesi. Mersin Üniversitesi Ĕ̆itim Fakültesi Dergisi, 16(3), 628-650.

Knuth, E. J. (2002). Secondary school mathematics teachers' conceptions of proof. Journal for Research in Mathematics Education, 33, 379-405.

Knuth, E., Choppin, J., \& Bieda, K. (2009). Middle school students' production of mathematical justifications. In D. Stylianou, M. Blanton, \& E. Knuth (Eds.), Teaching and learning proof across the grades: A K-16 perspective (pp. 153-170). New York, NY: Routledge.

Korkmaz, E., Tutak, T. ve İlhan, A. (2020). Ortaokul matematik ders kitaplarının matematik öğretmenleri tarafından değerlendirilmesi. Avrupa Bilim ve Teknoloji Dergisi, 18, 118128.

Kula, F. ve Ören-Vural, D. (2019). Matematik öğretiminde örnekler: Temel tanım, kavram ve yaklaşımlar. Bolu Abant İzzet Baysal Üniversitesi Ĕ̆itim Fakültesi Dergisi, 19(2), 569-586.

Lakatos, I. (1976). Proofs and refutations: The logic of Mathematics discovery. Cambridge: Cambridge University Press.

Millî Eğitim Bakanlığı, Talim ve Terbiye Kurulu Başkanlığı (2013). İlkokul ve ortaokul matematik dersi öğretim programı. Ankara: MEB.

Millı̂ Eğitim Bakanlığı, Talim ve Terbiye Kurulu Başkanlığı (2018). Ilkokul ve ortaokul matematik dersi öğretim programı. Ankara: MEB.

Newton, D. P., \& Newton, L. D. (2007). Could elementary mathematics textbooks help give attention to reasons in the classroom? Educational Studies in Mathematics, 64, 69-84. https://doi.org/10.1007/s10649-005-9015-z

Sevgi, S. ve Kartalcı, S. (2021). Üniversite öğrencilerinin matematiksel ispata yönelik görüşleri ile kavramsal-işlemsel yaklaşımlarının incelenmesi. Başkent University of Journal of Educaion, 8(1), 275-291.

Stacey, K., \& Vincent, J. (2009). Modes of reasoning in explanations in Australian eighth-grade mathematics textbooks. Educational Studies in Mathematics, 72(3), 271-288.

Stylianides, G. J. (2008). An analytic framework of reasoning-and-proving. For the Learning of Mathematics, 28(1), 916.

Stylianides, G. J. (2009). Reasoning and proving in school mathematics textbooks. Mathematical Thinking and Learning, $11,258-288$.

Şimşek, H. ve Yıldırım, A. (2018). Sosyal Bilimlerde Nitel Araştırma Yöntemleri (11. bas). Ankara: Seçkin Yayıncılık.

Thompson, D. R., Senk, S. L., \& Johnson, G. J. (2012). Opportunities to learn reasoning and proving high school mathematics textbooks. Journal for Research in Mathematics Education, 43, 253-295.

Türk Dil Kurumu [TDK]. (2005). Türkçe Sözlük. Türk Dil Kurumu Yayınları: 549, Türk Dil Kurumu, 4. Akşam Sanat Okulu Matbaası, Ankara.

Zeybek, Z., Üstün, A. ve Birol, A. (2018). Matematiksel ispatların ortaokul matematik ders kitaplarındaki yeri. Elementary Education Online, 17(3), 1317-1335. 
Extended Abstract

\section{Introduction}

With the recent updates in mathematics curricula in our country, it has become an important issue for students to think about why and how mathematical information is correct. This situation has increased the importance and role of the concept of proof. Textbooks are used as primary resources for both students and teachers. For this reason, it becomes important that the updates made are reflected in the textbooks. Based on this, the aim of this study is to examine the frequency of use of proof activities in the field of geometry and measurement in middle school 7th and 8th grade mathematics textbooks published in line with the changes in the curriculum in 2013 and 2018. For this purpose, the proof activities in the books used in 7th and 8th grade mathematics lessons in Sivas province and in the field of geometry and measurement were examined. The mathematical composition of Stylianides' theoretical framework of reasoning and proof was used to examine the textbooks.

\section{Method}

In this research, proof activities in four mathematics textbooks prepared according to 2013 and 2018 mathematics curricula were examined. Textbooks are selected from the books used in public schools affiliated to the Ministry of National Education. In this context, the method of working is document analysis. The process of examining the textbooks was carried out in two stages. First of all, the textbooks were examined in general and it was determined that the books had an order with introduction, development and conclusion sections. In these sections, it was determined that information aimed at reminding students of their previous knowledge or practices in which basic information and explanations about the subject were reinforced with examples and activities, and finally, evaluation activities were included. While classifying the textbooks, the proof activities in these mathematical studies were examined by focusing on the problem solving / setting, activities, and examples in which the students were active in the process. However, the exercises and assignments in the textbooks were not evaluated because they consist mostly of multiple-choice questions. Considering the purpose of the research among the four books examined, activities that do not include proof activities were not included in the study.

\section{Findings}

In this section, before examining the studies in the textbooks within the framework of the proof framework, a general examination was made in order to make a more detailed analysis and the number of examples, problems and activities used in the books was determined. Of the 442 activities in the textbooks, $378(85.52 \%)$ activities are examples, $38(8.59 \%)$ activities are activities, and $26(5.88 \%)$ activities are problems. As a result of the general examination, it is desired to reach a result in terms of how many of them can be considered as proof activities by reaching the number of studies in the field of geometry and measurement in the textbooks. In the 7th grade mathematics textbook in 2013, there were 7 assumptions, 9 generalizable examples, 1 representation, 5 rational, 4 definite patterns and 114 empirical arguments within the geometry and measurement learning domain, while in the 7th grade mathematics textbook published in 2018, 3 assumptions. 7 generalizable examples, 2 rational and 80 empirical arguments. Similarly, in the 8th grade mathematics textbook in 2018, there were 2 assumptions, 2 generalizable examples, 2 rational and 89 empirical arguments, while in the 8th grade mathematics textbook published in 2013, there were 2 assumptions, 35 generalizable examples include 65 empirical arguments and 1 rational argument.

\section{Result and Discussion}

The findings show that the number of problems, examples and activities examined in the field of geometry and measurement in the 7th and 8th grade mathematics textbooks published in 2018 is less than the number of problems, examples and activities in the 7th and 8th grade mathematics textbooks published in 2013. The reasons for this situation may be the simplifications made in the subjects and acquisitions within the revision studies made in the curriculum and the inadequacies in the preparation of the textbooks. The results show that the textbooks contain the most examples and the least problems. On the other hand, it has been determined that the problems 
involved are presented as multi-solution problem situations without setting up problems. When the proof activities in the textbooks were examined, it was found that the examples were mostly included in the empirical argument category. It was determined that the number of generalizable samples in the textbooks published in 2013 was higher than the generalizable sample number in the textbooks published in 2018. The results were obtained by examining the presentation forms of the activities in the textbooks. There may be differences in the presentation of the activities examined in the classroom environment and different results can be obtained from the classifications we make. This situation is seen as the limitation of our research. In line with the data obtained as a result, it was seen that not all types of proof in the frame were included in the textbooks. In line with the findings obtained, especially in textbooks, while rational, claim, notation and definite pattern proof classes are rarely encountered, predominantly generalizable examples and empirical arguments have been found. Possible pattern type has never been found.

\section{Araştırmanın Etik Taahhüt Metni}

Yapılan bu çalışmada bilimsel, etik ve alıntı kurallarına uyulduğu; toplanan veriler üzerinde herhangi bir tahrifatın yapılmadığı, karşılaşılacak tüm etik ihlallerde "Manisa Celal Bayar Üniversitesi Eğitim Fakültesi Dergisi ve Editörünün" hiçbir sorumluluğunun olmadığı, tüm sorumluluğun Sorumlu Yazara ait olduğu ve bu çalışmanın herhangi başka bir akademik yayın ortamına değerlendirme için gönderilmemiş olduğu sorumlu yazar tarafından taahhüt edilmiştir. 